\title{
Early lactation ratio of fat and protein percentage in milk is associated with health, milk production, and survival
}

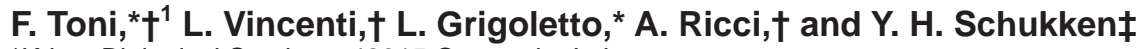 \\ *Kriton Biological Services, 42015 Correggio, Italy \\ †Department of Animal Pathology, School of Veterinary Medicine, University of Turin, 10095 Turin, Italy \\ $\ddagger Q$ uality Milk Production Services, Department of Population Medicine and Diagnostic Sciences, College of Veterinary Medicine, \\ Cornell University, Ithaca, NY 14853
}

\begin{abstract}
An observational study was conducted on 1,498 cows in 3 large Italian dairy farms. The objective of the study was to evaluate the prognostic value of early lactation fat-to-protein ratio in milk. In all 3 herds, an intensive herd health monitoring program was being practiced that included weekly visits and extensive data collection on health, reproduction, production, and culling. A milk sample was collected from all cows at approximately $7 \mathrm{~d}$ postpartum and the ratio of fat-to-protein percentage in this milk sample was measured. Animals with a fat-to-protein ratio in early lactation greater than 2.0 showed an increase in postpartum diseases such as retained placenta, left-displaced abomasums, metritis and clinical endometritis. We also observed a decrease in early lactation milk production but this was limited to cows in lactation 2 and higher when the fatto-protein ratio was greater than 2.0 in the early postpartum milk sample. Finally, an increased risk of being culled from the herd was observed, with the risk of culling increasing with increasing fat-to-protein ratio in the early lactation milk sample. No effect of fat-to-protein ratio was found on the incidence of clinical mastitis in the 3 herds. From this study, we conclude that analyses of milk components in early postpartum (6-9 days in milk), particularly the ratio of fat-to-protein percentage, is a valuable indicator of lipo-mobilization and the negative energy balance status in postpartum cows. Because a single milk sample is sufficient to provide valuable information, we suggest that this is a valuable addition to herd health programs on dairy farms.
\end{abstract}

Key words: fatty liver, acidosis, survival, milk production

Received April 29, 2010.

Accepted December 10, 2010.

${ }^{1}$ Corresponding author: Fausto.Toni@pfizer.com

\section{INTRODUCTION}

The periparturient period of the dairy cow is one of the most delicate periods in the productive and reproductive cycle. In the late dry period and early lactation, an insufficient DMI in combination with a high energy need due to initiation of milk production leads to a negative energy balance (NEBAL). The energy balance is defined as the difference between energy consumed and energy used for maintenance and production (Goff and Horst, 1997). Typically, fresh cows are not able to consume enough energy to meet their physiological energy requirements and, consequently, they enter into a NEBAL status (Doepel et al., 2002; Bauman and Griinari, 2003).

Different cows deal differently with this NEBAL status. All animals mobilize their internal energy resources in the form of fat deposits. Nonesterified fatty acids are utilized and oxidized to obtain energy (Drackley et al., 2005; LeBlanc et al., 2005). However, in a proportion of cows, the release of NEFA exceeds the ability of the liver to metabolize the fatty acids, and a proportion of the fatty acids are stored as triglycerides in the liver. The liver may use these triglycerides to produce ketone bodies (Goff and Horst, 1997). Large amounts of triglycerides in the liver and high de novo construction of ketone bodies may lead to a condition know as fatty liver disease (Drackley et al., 2005; Grummer, 2008). This metabolic state has been associated with several postpartum diseases such as retained placenta, metritis, endometritis, mastitis, displaced abomasal disorders, and clinical ketosis (Ingvartsen and Andersen, 2000; Drackley et al., 2005).

Milk production and test-day milk data may be used to monitor feed intake and nutrient balance (Duffield et al., 1997; Fleischer et al., 2001). Test-day plots of fat, protein, fat-to-protein ratio (FPratio), urea versus kilograms of milk, and milk urea versus protein have been described (Fleischer et al., 2001) as monitors of nutrient balance. Because milk fat concentration tends to increase and milk protein concentration tends to decrease during the postpartum negative energy balance, 
the early postpartum FPratio in milk was suggested (Duffield et al., 1997; Heuer et al., 1999) as a potential indicator of a lack of energy supply through feed. An FPratio that is greater than 1.5 has been shown to be indicative of energy deficiency (Duffield et al., 1997; Heuer et al., 1999). Heuer et al. (1999) reported that cows with a postpartum FPratio greater than 1.5 had higher risks for ketosis, displaced abomasum, ovarian cyst, lameness, and mastitis. Cows with this early lactation characteristic produced more milk but showed poor reproductive performance. The authors concluded that first test-day milk yield and FPratio were more reliable predictors of disease, fertility, and milk yield than was BCS or loss of BCS (Heuer et al., 1999). In this study, an elevated first test-day ratio of fat to protein was associated with an 8.6 times increased risk of leftdisplaced abomasums (LDA). Similarly, Geishauser et al. (1998) used first postpartum test-day milk sampled before a case of LDA to examine the association between milk yield, fat and protein percentage, and FPratio and LDA in dairy cows. Cases of LDA were matched with 3 controls per case by herd and calving date. Higher odds of LDA were found with lower milk yield, higher milk fat percentage, lower milk protein percentage, and a higher FPratio. These results were in accordance with other studies looking at these relationships (Cameron et al., 1998; LeBlanc et al., 2005; Van Winden et al., 2006).

During early lactation the connection between nutrient supply and milk production appears to be uncoupled in modern dairy cows. In the first $10 \mathrm{~d}$ of lactation, milk yield increases sharply, whereas nutrient intake only increases slowly and, therefore, the energy balance is considered at its nadir at approximately 7 to $14 \mathrm{~d}$ postpartum (Bauman and Griinari, 2003). However, the first test-day information is often obtained several weeks after the first $2 \mathrm{wk}$ in lactation (Geishauser et al., 1998, 1999) with a wide range. Therefore, test-day information may be valuable in identifying high-risk animals with persistent NEBAL symptoms, but the inconsistent timing of test-day information as it relates to DIM and the nadir of NEBAL is a limitation in its use across all cows in the herd. Hence, first postpartum test-day FPratio, although shown to be valuable, may not be the best and most consistent indicator of early lactation lipo-mobilization and metabolic challenge.

To better monitor NEBAL in early postpartum dairy cows, we devised a management system where a milk sample was consistently taken at approximately $7 \mathrm{~d}$ postpartum and evaluated for fat and protein percentages. The objective of this study was to evaluate the early postpartum FPratio in milk as a parameter indicating early lactation lipo-mobilization and predicting early lactation health, milk production, and time to culling during lactation in Holstein dairy cows.

\section{MATERIALS AND METHODS}

\section{Herd Descriptions}

The data were collected on 3 large Italian dairy herds with Holstein dairy cows. The total number of cows included in the study was 1,498 . These cows calved between December 1, 2004 and October 1, 2005. Herd sizes were 603,421 , and 474 for farms A, B, and C respectively, with $35.8 \%$ of animals being in their first lactation. Average daily milk production was between 33 and $40 \mathrm{~kg}$ per d and the corrected 305-d milk production was $9,330,9,746$, and $9,557 \mathrm{~kg}$, respectively. Two farms (A and $\mathrm{C}$ ) were using a rotary parlor (40 milking stands) and one farm (B) was milking in a double 12 herringbone. Cows were milked twice per day in all 3 farms. All farms used dried manure as bedding for the lactating cows. Dry cows and cows in the calving pen were bedded on a bedded pack with straw. Milk from these farms was exclusively used for production of Parmesan cheese. All farms used standard operating procedures for most important management processes on the farm. One of the farms (B) was ISO:9001 accredited for its dairy operations. High-quality data collection systems were present on the farms and included weekly herd health visits, monthly DHIA visits, and recording of all disease and reproductive events into a computerized database. Daily milk production was collected using Delaval milk meters and daily milk weight data was transferred from Alpro to the AfiFarm data management system (S.A.E. Afikim, Israel). All DHIA and milk production data was imported into the AfiFarm management system and reproduction and health data were recorded and managed with the AfiFarm system.

\section{Nutrition}

Total mixed ration was fed to the cows twice per day. The diet consisted of $50 \%$ concentrate $(8 \mathrm{~kg}$ of steamed, crushed corn; $2 \mathrm{~kg}$ of barley; and $3 \mathrm{~kg}$ of high-protein mix, consisting of soybean and sunflower seeds mixed with a mineral mix) and $50 \%$ forage ( $1 / 2$ grass hay and $1 / 2$ alfalfa, in accordance with the guidelines for the production of Parmesan cheese), with $17 \mathrm{~kg}$ of water for each cow added to the TMR. Because the milk was used exclusively for Parmesan cheese production, the use of corn silage was precluded from the diet). For dry cows, a dry diet consisting of ad lib forage (50\% hay and $50 \%$ alfalfa) with $2 \mathrm{~kg}$ of a purchased dry cow concentrate 
was fed. During the last 14 to $21 \mathrm{~d}$ of the dry period, the diet consisted of $40 \%$ of lactation cow ration (see above) and $60 \%$ of the early dry cow diet. During this period, anionic salts were added to the diet.

\section{Cow Measurements}

Disease definition and diagnostic criteria were consistent across farms. Most veterinary work was performed by the senior author (F. Toni). Written disease definitions were given to participating dairy producers. Milk fever was defined as a cow that was unable to rise or had cool extremities and sluggish rumen motility near the time of calving, but was successfully treated with calcium. A retained placenta was a retention of fetal membranes for at least $24 \mathrm{~h}$ after calving; for a puerperal metritis (metritis) diagnosis, a cow was febrile and had a purulent or fetid vaginal discharge, or an enlarged uterus detected by veterinary palpation at 3 to $10 \mathrm{~d}$ postpartum. The clinical endometritis definition was based on visual inspection by the herd veterinarian of the cervix at approximately 30 DIM (between 28 and 35 DIM) and was defined as visually abnormal mucus fluid present in the vagina or cervix (Sheldon et al., 2006), or through ultrasound detection of abnormal fluid in the uterus. Ketosis was defined as the presence of ketones in milk, measuring BHBA was at a cut-off point of $100 \mathrm{~mol} / \mathrm{L}$, and a displaced abomasum was an abomasum that was enlarged with fluid and/or gas and mechanically trapped in either the left or right side of the abdominal cavity. Mastitis was defined as any abnormality in milk or udder that resulted in a mastitis treatment by the herd manager.

All culling decisions were made by the herd manager. Paratuberculosis testing was performed at dry-off using ELISA on serum. When ELISA-positive animals showed clinical symptoms associated with paratuberculosis, the animals were culled. Sudden death was observed in all farms and was repeatedly shown to be associated with clostridium infections using both gross pathology and laboratory confirmation. Postpartum culling was defined as culling within $30 \mathrm{~d}$ of calving. Trauma was mostly leg trauma, often associated with cows slipping in the walkways. Culling for mastitis was done for both clinical mastitis and high SCC. Body condition score was performed by the same observer (F. Toni) in the week of dry-off and in the week after calving (5-12 d after calving). All herds participated in monthly complete herd DHIA testing. In addition, an additional milk sample (to be defined here as extra test was collected between 6 and 9 DIM from the morning milking, and evaluated for milk components. This additional milk sample was also evaluated for ketosis using the Ketolac (Hoechst, Germany) milk ketosis test (a semiquantitative, colorimetric test that measures the level of BHBA in the milk,). Milk components were evaluated using a Fossomatic 5000 milk analyzer (Foss Electric Co., Inc., San Antonio, TX).

\section{Statistical Methods}

All data were initially managed in the AfiFarm herd management software. This system is Microsoft Access based. Data were exported into spreadsheets and uploaded into statistical software. All statistical analyses were done using the SAS statistical system version 9.2 (SAS Institute, 2009). Descriptive statistics on all variables were performed and outliers investigated. No data were excluded in this stage of the analysis. New variables were calculated from the raw data, notably the FPratio in the early lactation additional test and the regular DHIA test results. The FPratio was calculated as the simple ratio between fat percentage in milk and protein percentage in milk. This variable was used as a categorical variable with a category size of 0.5 units. Based on previous research (Heuer et al., 1999), we used a ratio between 1.0 and 1.5 as the baseline (normal) category for comparison. The FPratio was used as the principle predictor for health events and culling, with correction for possible confounders as fixed effects, such as parity (categorized into 2 groups: first- and second and older-lactation animals), season of calving (summer: April to October, and winter: November to March), and herd.

The relationship between FPratio and health events was evaluated using a logistic regression analysis (SAS PROC GLIMMIX), where the health event was used as the outcome variable:

$$
\begin{gathered}
\text { Logit }(\text { health event })=\text { intercept }+ \text { FPratio } \\
+ \text { confounders }+ \text { interactions }+ \text { error }
\end{gathered}
$$

where health event was retained placenta, metritis, endometritis, LDA, or mastitis; FPratio was a categorical variable as defined above; and confounders were herd, calving season, lactation 1 versus lactation 2 and older, calving BCS, and diseases preceding the health event of interest. Obviously, the disease event retained placenta would occur before the measurement of the FPratio at 7 DIM. However, we assume that the process underlying the NEBAL was already in place at the time when placental retention was occurring. Two-way and relevant 3 -way interactions were evaluated for all models and only reported when statistically significant.

Daily milk production in the first $120 \mathrm{~d}$ of lactation was evaluated using mixed liner regression models run in PROC MIXED. First-lactation animals were evalu- 
ated separately from animals in higher lactations due to the stark difference in shape of the lactation curve. The initial model was

$$
\begin{gathered}
\text { Daily milk }=\text { intercept }+\operatorname{dim}+\text { herd }+ \text { FPratio } \\
+ \text { interactions }+ \text { complex error }
\end{gathered}
$$

where daily milk is the daily milk production of a cow, dim is a categorical variable indicating DIM in 10-d categories, herd is a categorical variable for herd, and FPratio is a categorical variable for FPratio in the extra test as defined above. Two-way and relevant 3-way interactions were evaluated for all models and only reported when statistically significant. The complex error term consisted of a repeated measures term for daily milk observations within cow, using an autoregressive $\mathrm{AR}(1)$ correlation and a random error term assumed to be independent and normally distributed with mean 0 . Milk weights were evaluated graphically using least squares means of the final model for the first $120 \mathrm{~d}$ of lactation.

Lactation survival was investigated using survival analysis. Cows were followed until $300 \mathrm{~d}$ in lactation, or earlier if culling occurred before that. Cows not culled during $300 \mathrm{~d}$ of follow-up were considered censored for this analysis. Life tables were constructed using the Kaplan Meier Product Limit estimators for the survival function. Cox Proportional Hazards survival analyses (PROC PHREG) were performed to relate early lactation FPratio to lactation survival, correcting for potential confounders such as parity, season, and herd. In this analysis, no intermediate variables, such as health outcome, were included because they are potentially affected (predicted) by FPratio in early lactation and would take away some of the numerical effect of this variable on lactation survival. Only variables that can be placed in time before the principle risk factor (FPratio in the extra test) were included as potential confounders. The final Cox regression model was

$$
\begin{aligned}
& \text { Culling Hazard }=\text { baseline hazard } \times \exp (\text { herd } \\
& + \text { season }+ \text { lactation }+ \text { BCS }+ \text { RP }+ \text { FPratio }),
\end{aligned}
$$

where exp is the exponent function, FPratio was a categorical variable as defined above, and confounders were herd, calving season, lactation 1 versus $2+$, calving $\mathrm{BCS}$, and retained placenta (RP). The baseline hazard is an unspecified hazard in Cox regression models. In all statistical analyses, statistical significance was decided based on at a cut-off value of $P<0.05$.

\section{RESULTS}

\section{Descriptive Analysis}

Descriptive data from the 3 herds during the study period are show in Table 1. Data are shown separately for first lactation and cows in lactation 2 and higher. Remarkable is the high percentage of fat in the extra test sample taken at approximately d 7 of lactation. The fat percentage was approximately $5.2 \%$ in these samples and was approximately $3.5 \%$ at first test. The first test day varied between animals, but was, on average, $40 \mathrm{~d}$ postpartum. This high fat percentage in the milk sample taken at approximately $7 \mathrm{~d}$ postpartum also resulted in a high FPratio in this extra test sample. Figure 1 shows the distribution categorized in increments of 0.5 for first-lactation and second and higherlactation cows. Few animals had an FPratio in the extreme categories $(<1$ and $>3)$, but 333 cows $(34.6 \%)$ and 161 heifers $(30.0 \%)$ had a value greater than 2 . Figure 2 shows the relationship between FPratio in the early test at approximately $7 \mathrm{~d}$ postpartum and the FPratio in the first test day postpartum (approximately 40 DIM). The correlation between these 2 parameters was calculated at 0.23 . The correlation between the FPratio in the extra test postpartum and the second test-day FPratio was much lower at 0.13. Milk ketosis testing using the Ketolac test on the extra test sample on $\mathrm{d} 7$ was positive in $23.1 \%$ of first-lactation animals and in $28.7 \%$ of lactation 2 and higher cows. Cows with a positive Ketolac test had a much higher FPratio at the extra test measured at the same time as the Ketolac test: 2.34 in Ketolac-positive animals and 1.64 in Ketolac test-negative animals.

The BCS of cows was, on average, 3.32 at dry-off and 3.13 at calving. Animals that had 2 BCS measurements across the dry period lost, on average, 0.20 condition score points from dry-off to calving. At calving, $1.3 \%$ of cows had a BCS of 4 or higher.

\section{Disease Events and Early Lactation FPratio}

The incidence of postpartum diseases was different between cows in different early lactation FPratio categories (Figure 3a,b) measured at approximately d 7 of lactation. The data show that the FPratio category with numerically the lowest incidence of disease was from 1 to 1.5. Particularly in first lactation cows (Figure 3a) this was evident, as the cows with an FPratio $<1$ had higher disease incidences. In the firstlactation cows, disease incidence of LDA, metritis, and endometritis also increased with increasing FPratio. In 
Table 1. Descriptive data of the cows included in the study (cow numbers, milk production, milk content, BCS, and disease incidences are shown; SE are shown in parentheses where relevant $)^{1}$

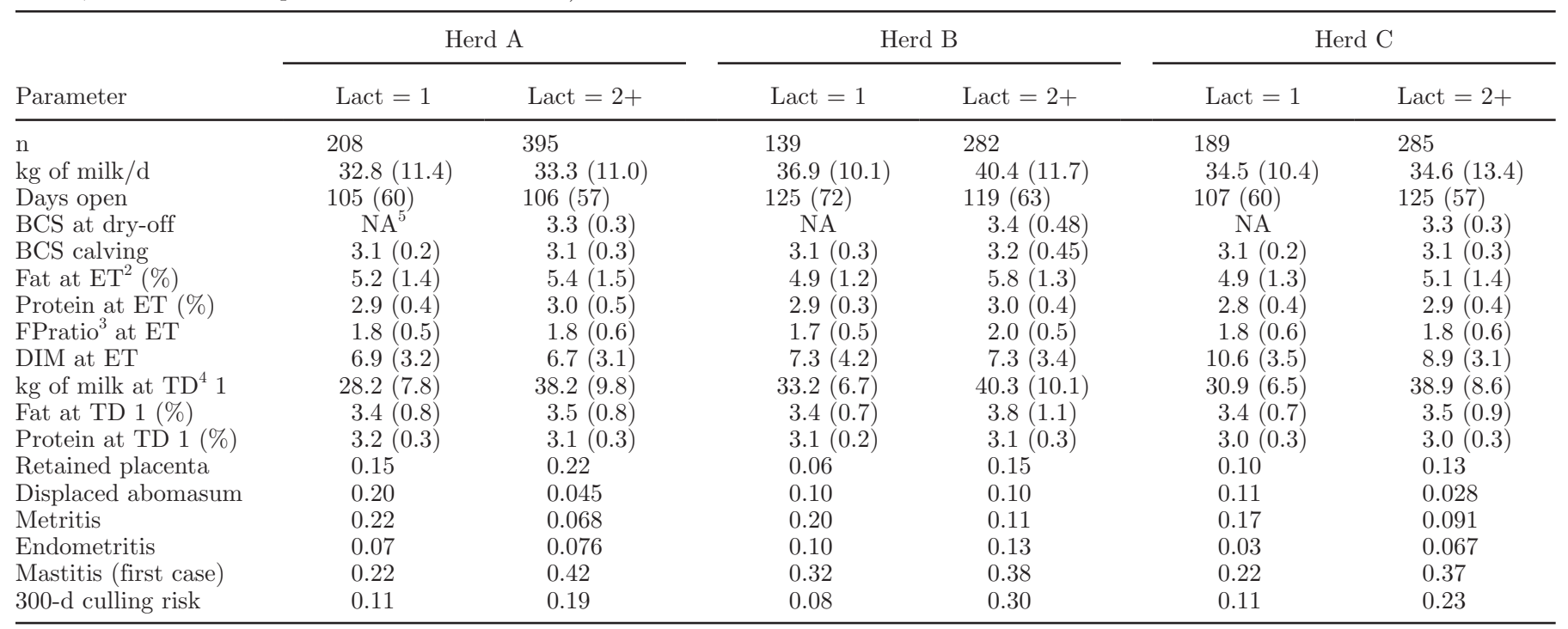

${ }^{1}$ Lact $=$ lactation.

${ }^{2} \mathrm{ET}$ is extra test and refers to the milk sample collected at approximately $7 \mathrm{~d}$ postpartum (no DHIA test included).

${ }^{3}$ Fat-to-protein ratio.

${ }^{4} \mathrm{TD}$ is test day and refers to the first DHIA test-day information (average $40 \mathrm{~d}$ postpartum).

${ }^{5}$ Not available.

first-lactation cows, the incidence of metritis and LDA was much higher compared with that of the cows in second and higher lactation. In older cows, the differences between FPratio categories $<1,1$ to 1.5 , and 1.5 to 2 were smaller, but disease incidence still increased with FPratio $>2$. In lactation $2+$ cows, the incidence of retained placenta was highest among all postpartum diseases and was particularly high (approximately 30\%)

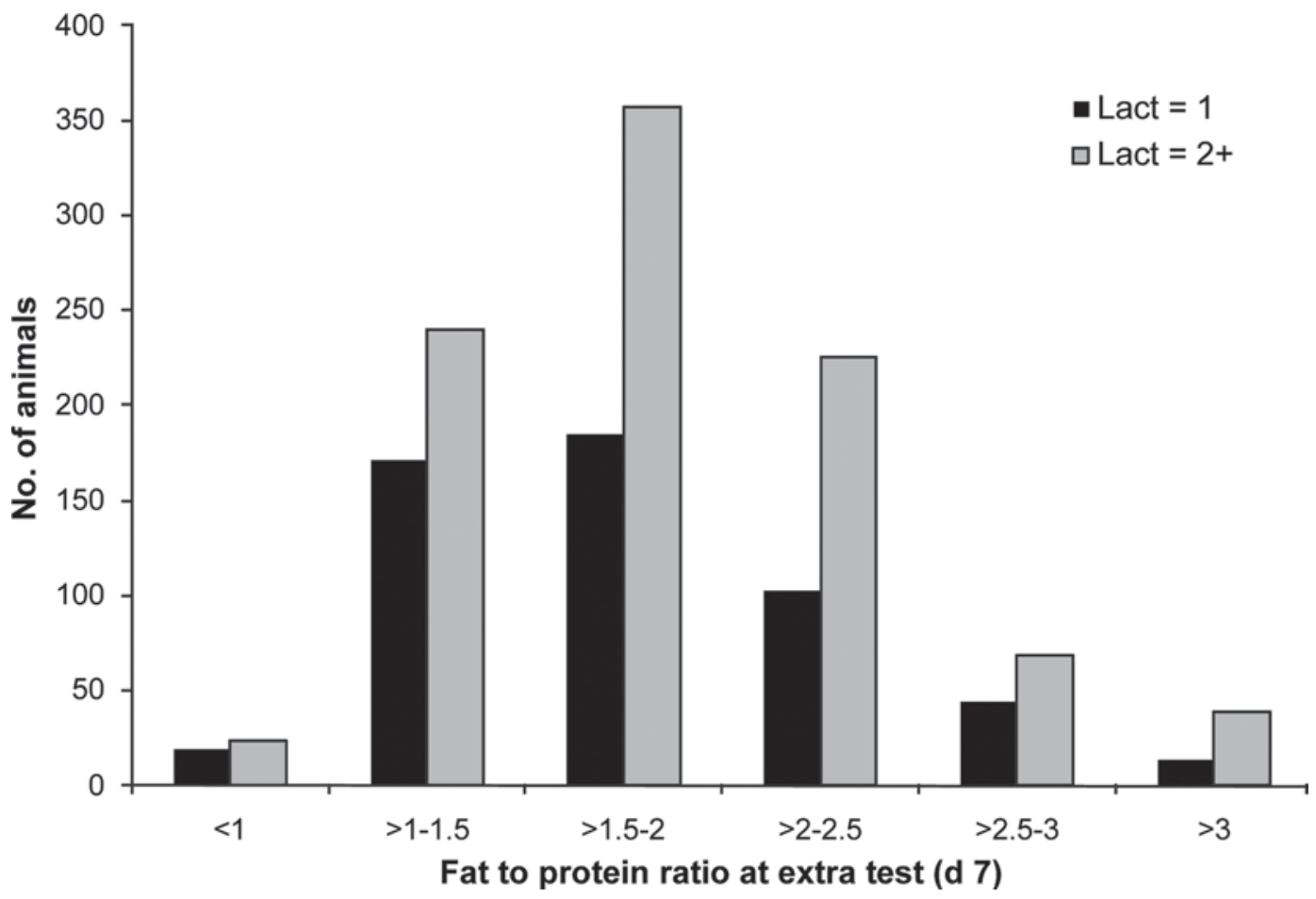

Figure 1. Distribution of fat-to-protein ratio in milk at approximately $7 \mathrm{~d}$ postpartum in heifers and cows. Lact $=$ lactation. 


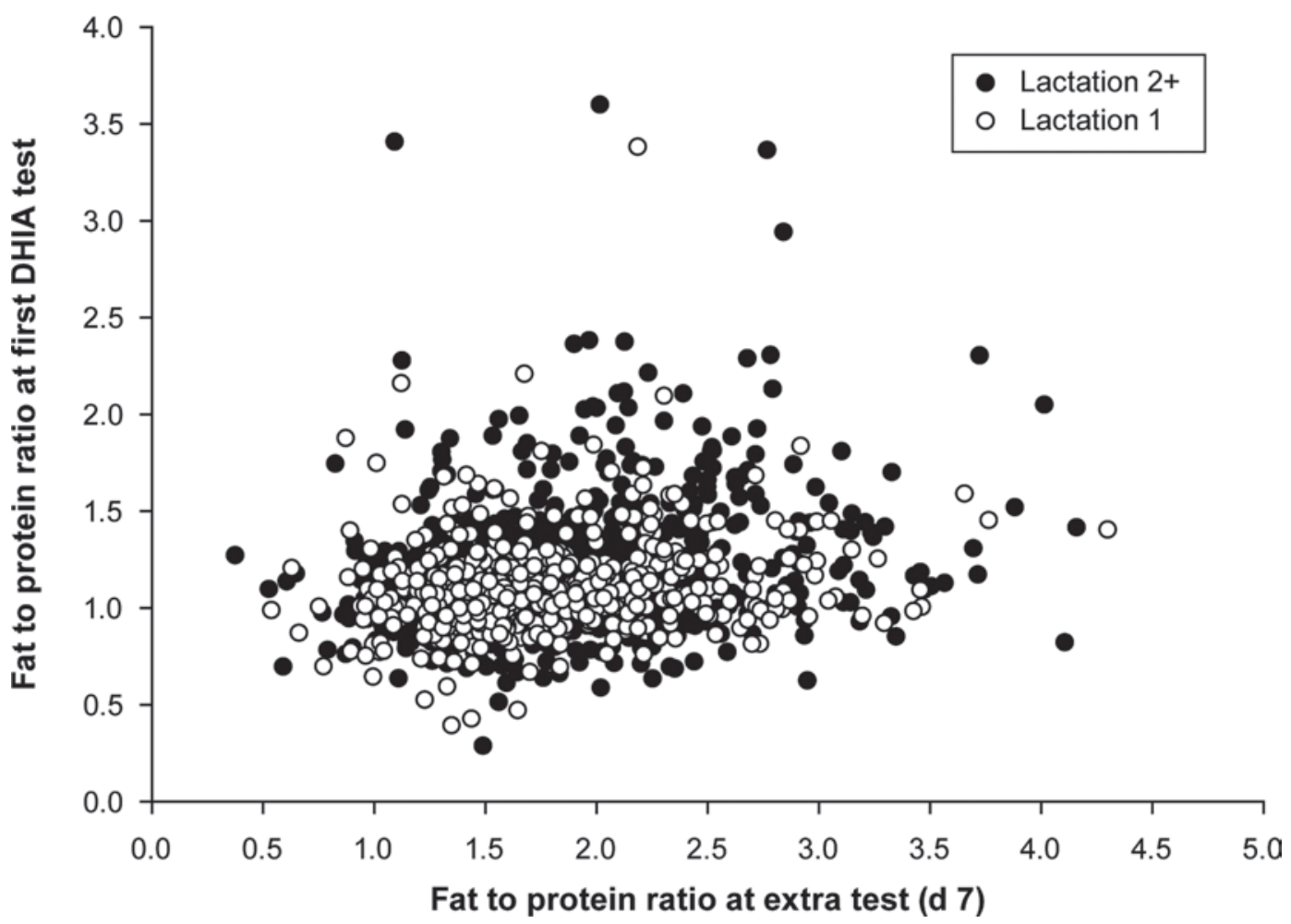

Figure 2. Relationship between fat-to-protein ratio in milk at approximately $7 \mathrm{~d}$ postpartum and fat-to-protein ratio in milk at first test day. Correlation between the 2 parameters was estimated at 0.20 for first-lactation cows and 0.25 for cows in lactation $2+$.

among cows with an FPratio $>2.5$. Retained placenta incidence was not as high in first-lactation cows, averaging approximately $15 \%$ over all FPratio categories. Clinical mastitis was high across all lactations and across all FPratio categories. No clear pattern in the clinical mastitis incidence was evident from the data in Figure $3 \mathrm{a}$ and $3 \mathrm{~b}$.

Logistic regression analysis of the health events data are presented in Table 2. In the final models, no significant interactions were present. The presented results in Table 2 are, therefore, the final models for all animals in the study. Logistic regression analysis confirmed the observations from Figure 3a and 3b in that an early lactation FPratio over 2.0 was a significant risk factor for retained placenta (assuming that the underlying process of NEBAL and fat mobilization was already present at the time of placental retention) and metritis and a value over 2.5 was a strong risk factor for LDA. Endometritis risk was not strongly affected by FPratio; only cows with an FPratio between 2.5 and 3 had a moderately increased risk. Cows that had a retained placenta earlier in lactation showed an increased risk for both metritis and endometritis. A case of metritis was predictive for a subsequent endometritis case in the same cow. No statistically significant risk factors were observed for clinical mastitis incidence. We separately analyzed the risk factors for early lactation clinical mastitis (clinical mastitis before 30 DIM) and also no relationship with FPratio was observed. The analyses were also performed without including any of the disease events since calving and BCS at calving. The results did not show an important change in odds ratio estimates for FPratio, indicating that these events occurring before the disease of interest were not confounding the relationship between FPratio and the disease of interest.

\section{FPratio and Shape of Lactation Curve}

The shape of the lactation curve in the first $120 \mathrm{~d}$ postpartum for each category of FPratio is shown in Figure $4 \mathrm{a}$ and $4 \mathrm{~b}$. The lactation curves in first-lactation cows are not very different, based on early-lactation FPratio. Only first-lactation cows with an FPratio below 1 showed a consistently lower milk production. In cows in lactation $2+$, the situation was different. The highest milk production was in cows with an FPratio in early lactation between 1 and 1.5, and 1.5 to 2 . Both an FPratio on $\mathrm{d} 7$ lower than 1 and over 2 resulted in lower milk production in the first $100 \mathrm{~d}$ of lactation. Production in early lactation was lower with an increasing FPratio. After approximately $100 \mathrm{~d}$ in lactation, the 

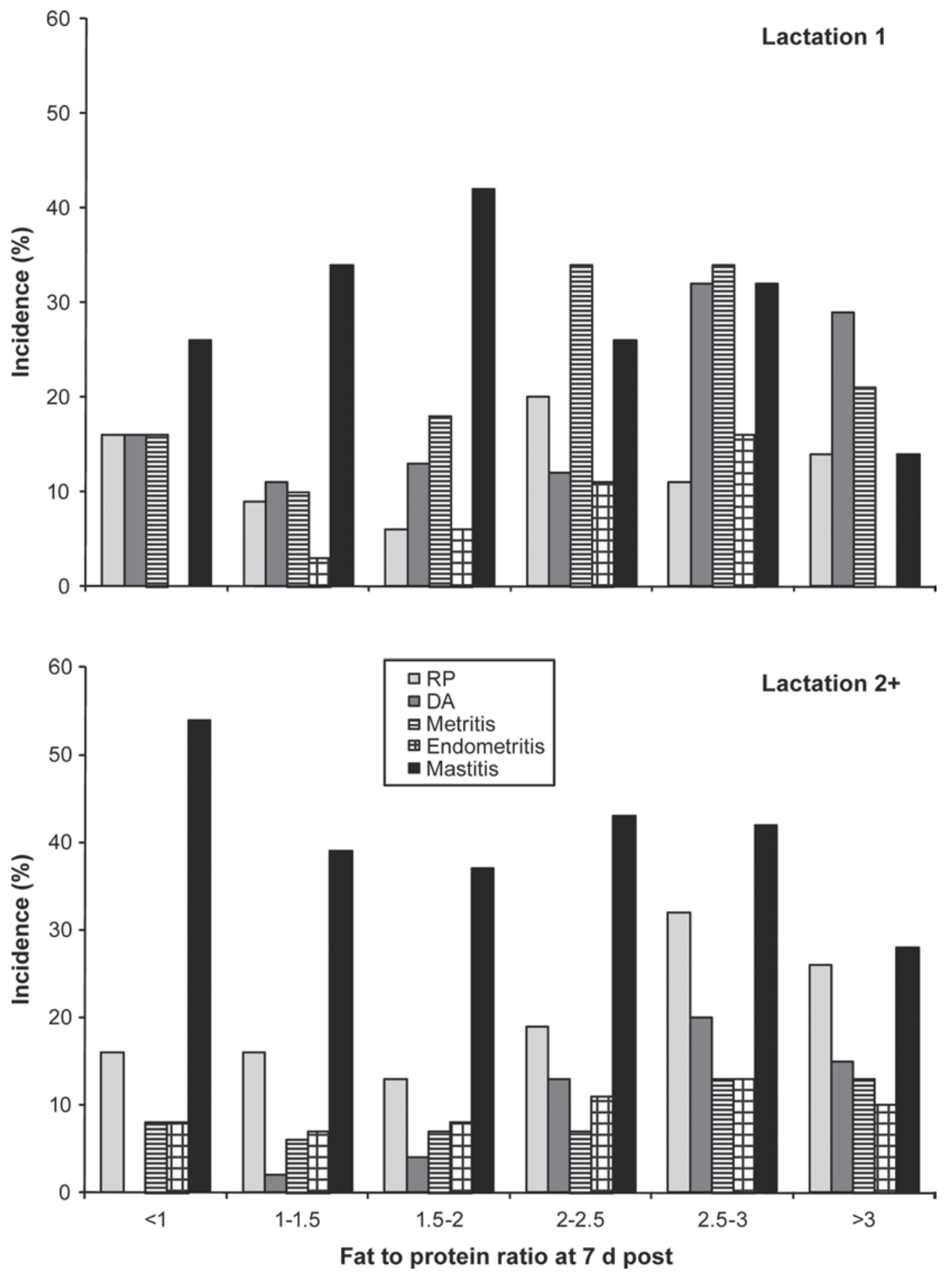

Figure 3. Disease incidence in heifers (top) and cows (bottom). RP = retained placenta, DA = displaced abomasum.

difference in milk production between animals with a different FPratio in early lactation was disappearing, with the exception of cows that had a fat protein inversion $(<1)$; these animals continued to produce less compared with herd mates.
Mixed model linear regression confirmed these findings with a significant 3 -way interaction of lactation number, FPratio, and DIM category $(P<0.0001)$. The F-test for FPratio in early lactation was statistically significant $(P<0.0001)$. When the daily production 
Table 2. Logistic regression models for retained placenta, metritis, endometritis, left-displaced abomasums (LDA), and clinical mastitis ${ }^{1}$

\begin{tabular}{|c|c|c|c|c|c|}
\hline Risk factor & $\begin{array}{l}\text { Retained } \\
\text { placenta }\end{array}$ & Metritis & Endometritis & LDA & $\begin{array}{l}\text { Clinical } \\
\text { mastitis }\end{array}$ \\
\hline Herd $\mathrm{A}$ to $\mathrm{C}$ & In model & In model & In model & In model & In model \\
\hline Calving season & In model & In model & In model & In model & In model \\
\hline Calving BCS & $0.3(0.2-0.5)^{* *}$ & $0.3(0.2-0.5)^{* *}$ & $0.7(0.4-1.2)$ & $1.0(0.6-1.9)$ & $1.1(0.8-1.6)$ \\
\hline \multicolumn{6}{|l|}{ FP ratio ${ }^{2}$} \\
\hline$<1$ & $1.2(0.5-3.0)$ & $1.6(0.6-4.6)$ & $0.6(0.1-2.9)$ & $1.1(0.3-3.9)$ & $1.2(0.6-2.3)$ \\
\hline$\geq 2.5$ to 3 & $2.3(1.3-3.9)^{*}$ & $3.8(2.1-7.0)^{* *}$ & $2.1(1.0-4.2)^{*}$ & $5.5(3.0-10.2)^{* *}$ & $1.1(0.7-1.7)$ \\
\hline$\geq 3$ & $2.0(1.0-4.1)^{*}$ & $2.7(1.1-6.4)^{*}$ & $1.1(0.4-3.4)$ & $4.7(2.0-10.8)^{* *}$ & $0.5(0.3-1.0)^{*}$ \\
\hline Retained placenta yes versus no & - & $0.2(0.1-0.3)^{* *}$ & $3.6(2.3-5.7)^{* *}$ & $1.2(0.7-2.1)$ & $1.0(0.7-1.4)$ \\
\hline Metritis yes versus no & - & - & $3.7(2.3-6.1)^{* *}$ & $1.5(0.9-2.4)$ & $1.0(0.7-1.4)$ \\
\hline LDA yes versus no & - & - & - & - & $0.9(0.6-1.3)$ \\
\hline
\end{tabular}

${ }^{1}$ The table shows odds ratios with their $95 \%$ confidence intervals in parentheses. Herd and calving season were corrected for in the model.

${ }^{2}$ Fat-to-protein ratio.

${ }^{*} P<0.05 ; * * P 0.01$.

data were analyzed separately for first-lactation cows and later-lactation cows, the effects of FPratio were somewhat opposite in first-lactation and later-lactation cows. The results are presented in Table 3. Firstlactation cows with an FPratio greater than 1.5 but less than 3 had a significantly higher milk production compared with those with an FPratio of 1 to 1.5. The increase in production was approximately $0.8 \mathrm{~kg}$ per $\mathrm{d}$ (Table 3). First-lactation cows with an FPratio $<1$ or $>3$ produced approximately $0.6 \mathrm{~kg}$ per d less than cows with an FPratio from 1 to 1.5, but this was not statistically significant. In contrast, cows in lactation 2 and higher with an FPratio $>2.5$ produced approximately $2.0 \mathrm{~kg}(P<0.05)$ less compared with cows with an FPratio between 1 and 1.5 (Table 3). Also, cows with an FPratio inversion $(<1)$ produced approximately 2.5 $\mathrm{kg}$ of milk less $(P<0.05)$ compared with cows with an FPratio between 1 and 1.5. Autocorrelation was high, with an estimated $\mathrm{AR}(1)$ correlation of 0.83 ; residual variance was estimated at $79.9 \mathrm{~kg}$.

\section{FPratio and Lactation Survival}

Total culls during the follow-up period were 277 and the main cull reasons were mastitis (80 cows), Johne's disease (77 culls), death (30 culls), trauma (32 culls), fertility and postpartum problems (28 culls), and low production (12 culls). The rate of culling was modeled using the Cox regression model. The final model is shown in Table 4. Significant predictors of the rate of culling in this model were first-lactation cows, which had a lower rate of culling compared with cows in lactation 2 and higher. However, the direction of effects of FPratio on culling was similar in first-lactation animals compared with animals in lactation 2 and higher. The FPratio at the extra test at $7 \mathrm{~d}$ postpartum was a significant predictor. Culling was lowest in the reference category of 1 to 1.5. All other categories had higher culling, and the cull rate increased with increasing value of the early postpartum FPratio. Categories 2 to $2.5,2.5$ to 3 , and $>3$ had a statistically significant higher culling hazard compared with the reference category of 1 to 1.5 that was $1.5,2.5$, and 3.1 times larger, respectively. Cows with an FPratio inversion $(<1)$ also had an increased cull rate, but this was not statistically significant. Figure 5 shows the negative log survivor function for the cows in each of the FPratio categories. The curves represent the cumulative risk of culling for cows in each of the categories. The risk of culling was particularly high in the first $30 \mathrm{~d}$ of lactation in cows with an FPratio greater than 2.

\section{DISCUSSION}

The results in this study indicate that cows with a very high FPratio in milk in early lactation suffer from both increased disease and culling incidence. In lactation 2 and higher cows, an increase in FPratio was also associated with decreased milk production, particularly in early lactation. Milk production later in lactation was similar to that of cows with a lower FPratio, but this was a somewhat biased conclusion because culling had removed differentially more cows from the higher FPratio categories. Surprisingly, cows in first lactation with an increased FPratio did suffer a higher risk of postpartum diseases and culling, but this was not associated with decreased milk production unless the FPratio was extremely high or low. Other studies have 

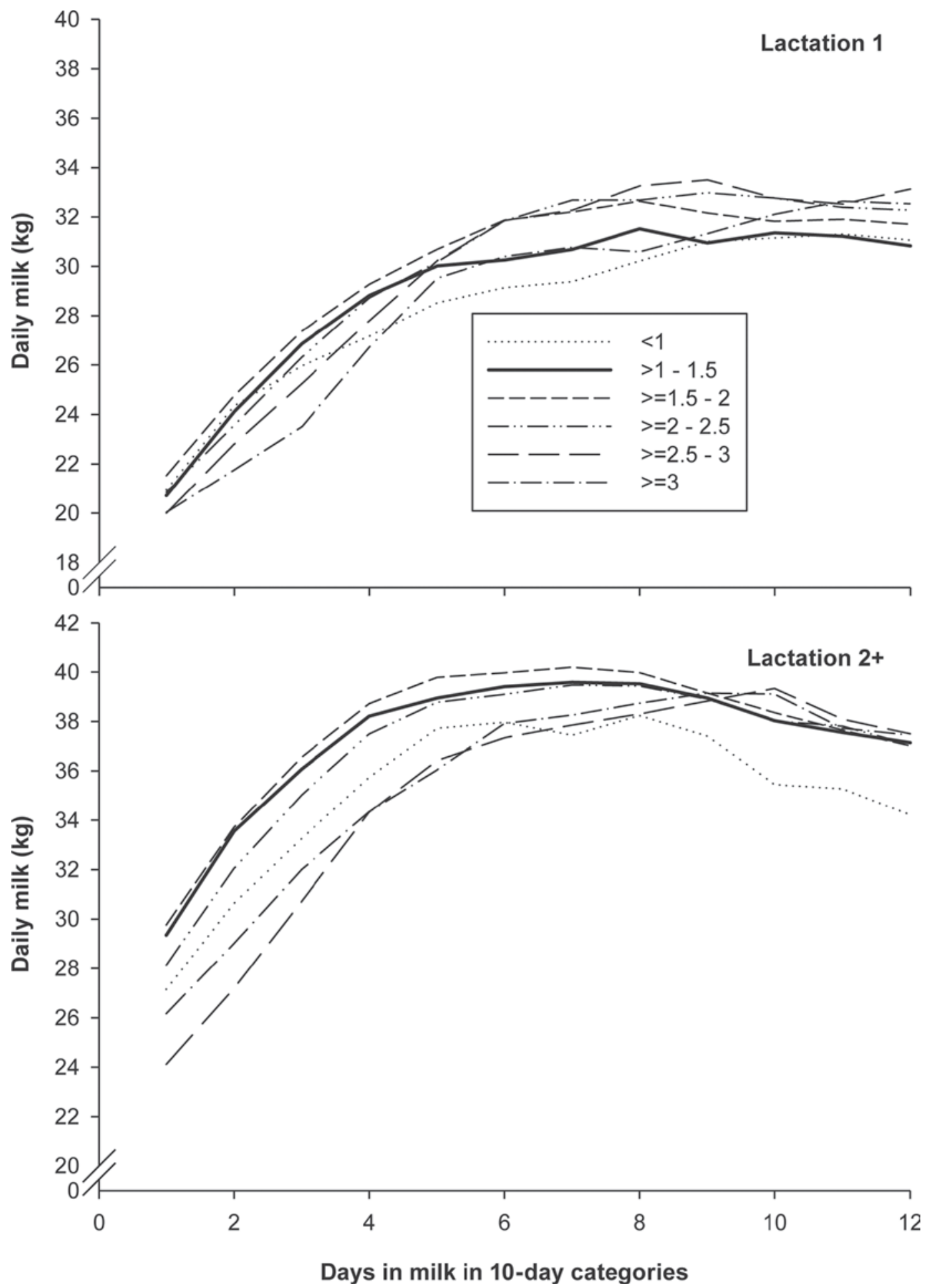

Figure 4. Milk production in kilograms per day by DIM in first-lactation animals (top) and animals in lactation 2 and higher (bottom) for each of the early lactation fat-to-protein ratio categories. Data are shown for the first 120 DIM.

also reported on the remarkable high rate of metritis in first-lactation cows and the relatively small effect of these metritis cases on subsequent fertility (Markusfeld and Ezra, 1993). Apparently, heifers were at risk of disease, and FPratio in early lactation was a significant predictor of disease, but being in a metabolically 
Table 3. Regression parameters and their standard error of fat-to-protein ratio (FPratio) in mixed linear regression models of daily milk production for first-lactation and second- and higher-lactation cows

\begin{tabular}{lccccccc}
\hline & \multicolumn{3}{c}{ First lactation } & & \multicolumn{2}{c}{ Second and higher lactation } \\
\cline { 2 - 3 } \cline { 7 - 8 } FPratio & Estimate & SE & P-value & & Estimate & SE & $P$-value \\
\hline$<1$ & -0.63 & 0.48 & 0.19 & & -2.38 & 0.65 & 0.0002 \\
$\geq 1$ to 1.5 & Baseline & & & & Baseline & & \\
$\geq 1.5$ to 2 & 0.86 & 0.21 & $<0.0001$ & & 0.41 & 0.25 & 0.099 \\
$\geq 2$ to 2.5 & 0.85 & 0.25 & 0.0006 & & -0.43 & 0.28 & 0.13 \\
$\geq 2.5$ to 3 & 0.72 & 0.34 & 0.031 & & -2.40 & 0.43 & $<0.0001$ \\
$\geq 3$ & -0.55 & 0.57 & 0.33 & & -1.81 & 0.56 & 0.0011 \\
\hline
\end{tabular}

challenged status did not result in impaired milk production. Some bias in this data exists, as a portion of affected animals was culled from the herd.

The 3 herds in this study provided us with very precise data. However, these herds may or may not be representative of a larger population. In general, these herds are considerably larger than other dairy herds in this region and was specifically managed for the production of Parmesan cheese.

The emerging picture from these data are that fat mobilization in early lactation, as it led to higher FPratios in milk, was associated with higher disease incidence in all cows and a lower early lactation production in lactation 2 and older cows. Even though our data measured early lactation fat mobilization more accurately than what was reported in earlier studies, a similar conclusion emerged from our data as that reported in other studies. Heuer et al. (1999) reported that the best cut-off for disease incidence production would be an FPratio of 1.5; although our data supported that with regard to disease incidence, the real negative effect on milk production and herd survival appeared to start at a value $>2.0$. In the present study, FPratio was measured in milk earlier in lactation compared with that in studies using the first DHIA test, and, on average, fat percentage in milk is higher at that point in time (see Table 1). The average fat percentage in milk on $\mathrm{d} 7$ of lactation in the 3 study farms was approximately $5 \%$, importantly higher than the average fat percentage in the first DHIA test-day sample at approximately $3.5 \%$. Also, the protein percentage in milk was approximately $0.2 \%$ lower in the early-lactation milk sample compared with the first DHIA test-day sample. The information in Figure 2 also suggests that the correlation between FPratio in early lactation and at first DHIA test is not very strong. We included the FPratio of the first (and later) DHIA test in all of our disease regression models, but it was never significant when the FPratio of the extra test at $\mathrm{d} 7$ was included in the model (data not shown). Similarly, BCS at calving, or change in BCS across the dry period never replaced FPratio on d7 with regard to predicting disease, production, or culling (Table 3). In our data, the correlation between BCS at calving and FPratio was essentially nonexistent $(\mathrm{r}=0.01)$, emphasizing the previously reported notion that BCS in itself is not predictive of metabolic aberrations (Bobe et al. 2004). Our data showed a negative correlation between BCS at calving and the risk of retained placenta and metritis (Table 3). Cows in these 3 herds showed no evidence for overconditioning, as they tended to lose a quarter point of BCS during the dry period and only $1 \%$ of cows might be considered overconditioned at calving.

Although the precise cut-off for an increased FPratio at $\mathrm{d} 7$ is somewhat difficult to define from our data (either $>1.5$ or $>2$ ), the opposite is true for an inversion

Table 4. Results of Cox regression survival analysis ${ }^{1}$

\begin{tabular}{lccc}
\hline Risk factor & Estimate (SE) & $P$-value & Hazard ratio \\
\hline Herd & In model & - & - \\
Calving season & In model & - & - \\
Lactation 1 & $-0.93(0.15)$ & $<0.0001$ & \\
Lactation 2+ & Baseline & & \\
FPratio $^{2}$ & & 0.32 & 1.46 \\
$<1$ & $0.38(0.38)$ & & 1.18 \\
$\geq 1$ to 1.5 & Baseline & 0.33 & 1.47 \\
$\geq 1.5$ to 2 & $0.16(0.17)$ & 0.03 & 2.17 \\
$\geq 2$ to 2.5 & $0.39(0.18)$ & 0.0006 & 3.06 \\
$\geq 2.5$ to 3 & $0.78(0.23)$ & $<0.0001$ & \\
$\geq 3$ & $1.12(0.27)$ & & \\
\hline
\end{tabular}

${ }^{1}$ For each risk factor the parameter estimate (standard error), $P$-value, and hazard ratio are presented. Herd and calving season were corrected for in the model.

${ }^{2}$ Fat-to-protein ratio. 


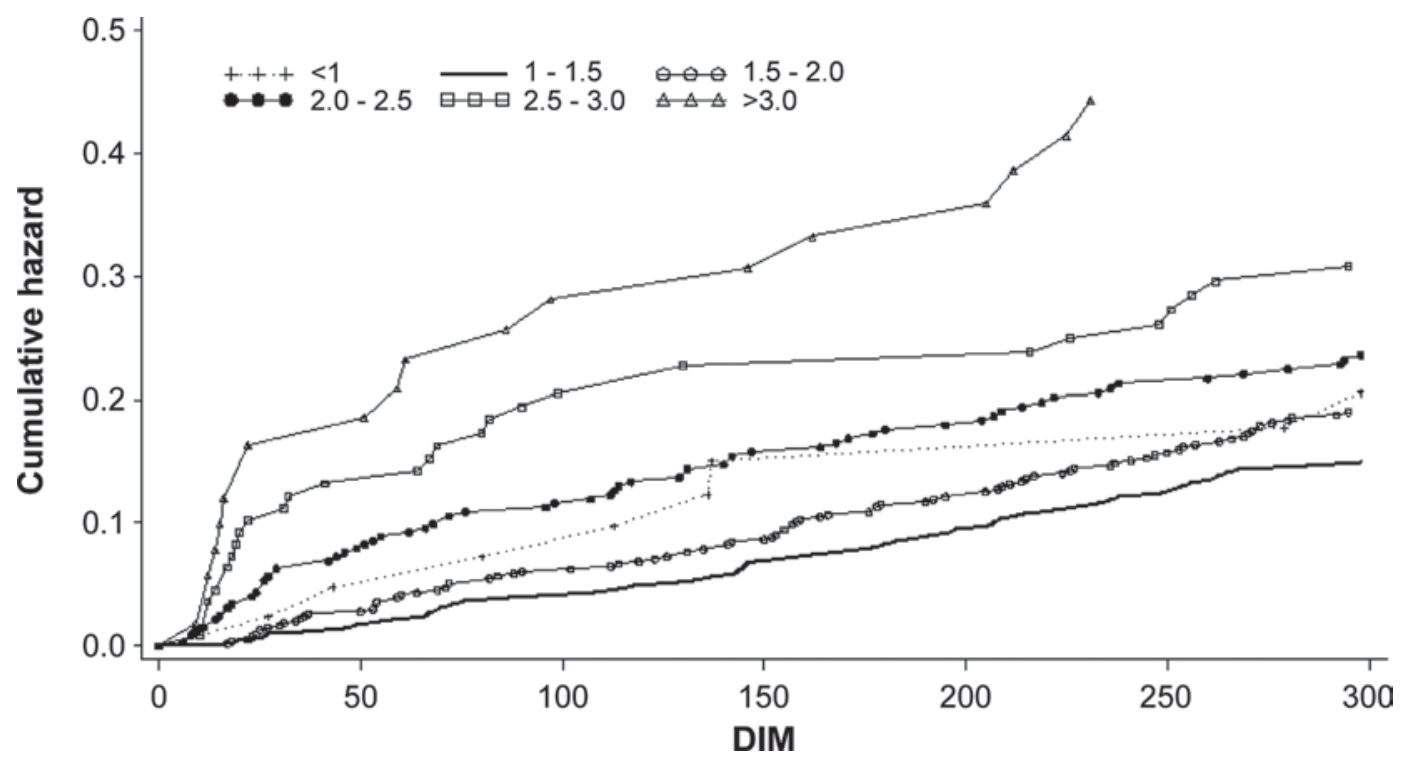

Figure 5. Cumulative hazard for the early lactation fat-to-protein ratio categories.

of this ratio. Cows with a fat percentage that is lower than their protein percentage in milk in early lactation showed a higher disease incidence, increased culling, and a decreased milk production, both in early lactation and during the total lactation. Subacute ruminal acidosis could decrease fat in milk, leading to a possible inversion of the ratio with protein: consequences of SARA include feed intake depression, decreased fiber digestion, milk fat depression, diarrhea, laminitis, liver abscesses, increased production of bacterial endotoxin, and inflammation characterized by increases in acute phase proteins (Plaizier et al., 2008). It should be understood that there were only few animals in these 2 categories (a total of 43 animals across lactations).

In these data, no significant relationship between FPratio in early lactation and clinical mastitis was observed. Also, no relationship between any of the postpartum diseases such as retained placenta existed. This is in contrast to findings from Schukken (1989) and Suriyasathaporn et al. (1999) who observed that cows in severe negative energy balance had an impaired leukocyte function and that cows suffering from retained placenta also had a higher risk of clinical mastitis. Clinical mastitis incidence was high in the 3 farms in our study across lactations (Table 1). Other factors may have predisposed the animals to clinical mastitis that overwhelmed a possible relationship with negative energy balance and early postpartum diseases. However, Duffield et al. (2009), in a large Canadian field study, also observed no relationship between postpartum ketosis and clinical mastitis incidence.
LeBlanc et al. (2005) observed in a field study on 20 Canadian dairy farms that cows with subclinical ketosis were 3.4 times more likely to develop LDA, based on a milk ketone test at 7 to $14 \mathrm{~d}$ postpartum. Similarly, in our data, cows with an early lactation FPratio $>2$ had an approximate 4 times higher risk of LDA compared with that of cows with an FPratio between 1 and 2 .

These data provide evidence that an extra test of milk fat and milk protein percentage at approximately $1 \mathrm{wk}$ postpartum provides valuable information for the remainder of lactation. When logistics of such tests can be resolved (i.e., in-line testing), then this extra test can be a very practical guide for the herd manager. In-line testing would allow for multiple measurements in early lactation, potentially providing even better information. Cows with very high lipo-mobilization, as shown through a high FPratio in early lactation, may be flagged for additional attention to prevent disease occurrence and milk loss (Duffield et al., 2003) or to diagnose postpartum problems earlier. In the herds in this study, the percentage of animals with an FPratio greater than or equal to 2 was $30.0 \%$ in first-lactation cows and $34.9 \%$ in second- or higher-lactation cows. Also, cows with an inversion of fat and protein percentage (4 and 3\%, respectively, for lactation 1 and $2+$ ) should be flagged for additional attention. An increase in FPratio in a significant proportion of early-lactation cows signals a transition problem that should be dealt with at the herd or group level with cows in the early dry period and transition period (Bobe et al., 2004; Grummer et al., 2004; Mulligan et al., 2006). The cur- 
rent study was not specifically designed to develop a cut-off value for the percentage of animals with a high FPratio at which transition management should be addressed. However, given the observed relationships with disease and the effect of lower production and increased culling, a significant effect on herd performance may be expected when $10 \%$ or more of cows in early lactation show an FPratio greater than or equal to 2.0.

\section{CONCLUSIONS}

Analysis of milk components in early postpartum (6-9 DIM), particularly the FPratio, is a valuable indicator of lipo-mobilization and the NEBAL in postpartum cows. The FPratio in milk with a value outside the range from 1 to 2 was a strong predictor of cow health events, early milk production performance, and survival in the current lactation. Because a single milk sample is sufficient to provide valuable information, we suggest that this may be a valuable addition to herd health programs on dairy farms.

\section{ACKNOWLEDGMENTS}

The authors acknowledge the support and interest of the participating dairy farms in this study.

\section{REFERENCES}

Bauman, D. E., and J. M. Griinari. 2003. Nutritional regulation of milk fat synthesis. Annu. Rev. Nutr. 23:203-227.

Bobe, G, J. W. Young, and D. C. Beitz. Invited review: Pathology, etiology, prevention, and treatment of fatty liver in dairy cows. 2004. J Dairy Sci. 87:3105-3124.

Cameron, R. E. B., P. B. Dyk, T. H. Herdt, J. B. Kaneene, R. Miller, H. F. Bucholtz, J. S. Liesman, M. J. Vandehaar, and R. S. Emery. 1998. Dry cow diet, management, and energy balance as risk factors for displaced abomasums in high producing dairy herds. J. Dairy Sci. 81:132-139.

Doepel, L., H. Lapierre, and J. J. Kennelly. 2002. Peripartum performance and metabolism of dairy cows in response to prepartum energy and protein intake. J. Dairy Sci. 85:2315-2334.

Drackley, J. K., H. M. Dann, G. N. Douglas, N. A. J. Guretzky, N. B. Litherland, J. P. Underwood, and J. J. Loor. 2005. Physiological and pathological adaptations in dairy cows that may increase susceptibility to periparturient diseases and disorders. Ital. J. Anim. Sci. 4:323-344.

Duffield, T. F., D. F. Kelton, K. E. Leslie, K. D. Lissemore, and J. H. Lumsden. 1997. Use of test day milk fat and milk protein to detect subclinical ketosis in dairy cattle in Ontario. Can. Vet. J. 38:713-718.
Duffield, T. F., S. LeBlanc, R. Bagg, K. Leslie, J. Ten Hag, and P. Dick. 2003. Effect of a monensin controlled release capsule on metabolic parameters in transition dairy cows. J. Dairy Sci. 86:1171-1176.

Duffield, T. F., K. D. Lissemore, B. W. McBride, and K. E. Leslie. 2009. Impact of hyperketonemia in early lactation dairy cows on health and production. J. Dairy Sci. 92:571-580.

Fleischer, P., M. Metzner, M. Beyerbach, M. Hoedemaker, and W. Klee. 2001. The relationship between milk yield and the incidence of some diseases in dairy cows. J. Dairy Sci. 84:2025-2035.

Geishauser, T., K. Leslie, T. Duffield, and V. Edge. 1999. The association between first DHI milk-test parameters and subsequent displaced abomasum diagnosis in dairy cows. Berl. Munch. Tierarztl. Wochenschr. 112:1-4.

Geishauser, T. D., K. E. Leslie, T. F. Duffield, and V. L. Edge. 1998 An evaluation of protein/fat ratio in first DHI test milk for prediction of subsequent displaced abomasum in dairy cows. Can. J. Vet. Res. 62:144-147.

Goff, J. P., and R. L. Horst. 1997. Physiological changes at parturition and their relationship to metabolic disorders. J. Dairy Sci. 80:1260-1268.

Grummer, R. R. 2008. Nutritional and management strategies for the prevention of fatty liver in dairy cattle. Vet. J. 176:10-20.

Grummer, R. R., D. G. Mashek, and A. Hayirli. 2004. Dry matter intake and energy balance in the transition period. Vet. Clin. North Am. Food Anim. Pract. 20:447-470.

Heuer, C., Y. H. Schukken, and P. Dobbelaar. 1999. Postpartum body condition score and results from the first test day milk as predictors of disease, fertility, yield, and culling in commercial dairy herds. J. Dairy Sci. 82:295-304.

Ingvartsen, K. L., and J. B. Andersen. 2000. Integration of metabolism and intake regulation: A review focusing on periparturient animals. J. Dairy Sci. 83:1573-1597.

LeBlanc, S. J., K. E. Leslie, and T. F. Duffield. 2005. Metabolic predictors of displaced abomasum in dairy cattle. J. Dairy Sci. $88: 159-170$.

Markusfeld, O., and E. Ezra. 1993. Body measurements, metritis, and postpartum performance of first lactation cows. J. Dairy Sci. $76: 3771-3777$.

Mulligan, F. J., L. O'Grady, D. A. Rice, and M. L. Doherty. 2006. A herd health approach to dairy cow nutrition and production disease of the transition cow. Anim. Reprod. Sci. 96:331-353.

Plaizier, J. C., D. O. Krause, G. N. Gozho, and B. W. Mc Bride. 2008. Subacute ruminal acidosis in dairy cows: The physiological causes, incidence and consequences. Vet. J. 176:21-31.

SAS Institute. 2009. SAS Institute Inc., Cary, NC.

Schukken, Y. H. 1989. Retained placenta and mastitis. Cornell Vet. $79: 129-131$.

Sheldon, I. M., G. S. Lewis, S. LeBlanc, and R. O. Gilbert. 2006 Defining postpartum uterine disease in cattle. Theriogenology 65:1516-1530.

Suriyasathaporn, W., A. J. Daemen, E. N. Noordhuizen-Stassen, S. J. Dieleman, M. Nielen, and Y. H. Schukken. 1999. Beta-hydroxybutyrate levels in peripheral blood and ketone bodies supplemented in culture media affect the in vitro chemotaxis of bovine leukocytes. Vet. Immunol. Immunopathol. 68:177-186.

Van Winden, S. C. L., R. Jorritsma, K. E. Müller, and J. P. T. M. Noordhuizen. 2003. Feed intake, milk yield, and metabolic parameters prior to left displaced abomasum in dairy cows. J. Dairy Sci. $86: 1465-1471$ 